\title{
Influence of Green Tea Extract with Different Concentrations of Epigallocatechin Gallate on Calvaria Bone Repair of Ovariectomized Rats
}

\author{
Influencia del Extracto de Té Verde con Diferentes Concentraciones de Galato de \\ Epigalocatequina sobre la Reparación Ósea de Calvaria de Ratas Ovariectomizadas
}

\author{
Luana Cristina de Freitas; Luiz Gustavo de Sousa; Guilherme Luciano Leite; Priscilla Hakime Scalize; \\ Dimitrius Leonardo Pitol; Mariah Acioli Righetti; Vitória Ricardo; Edneia Corrêa de Mello; \\ Karina Fittipaldi Bombonato-Prado; Simone Cecilio Hallak Regalo \& Selma Siessere
}

FREITAS, L. C.; SOUSA, L. G.; LEITE, G. L.; SCALIZE, P. H.; PITOL, D. L.; RIGHETTI, M. A.; RICARDO, V.; MELLO, E. C.; BOMBONATO-PRADO, K. F.; REGALO, S. C. H. \& SIESSERE, S. Influence of green tea extract with different concentrations of epigallocatechin gallate on calvaria bone repair of ovariectomized rats. Int. J. Morphol., 37(4):1325-1330, 2019.

SUMMARY: Impairing osteoporosis progression is a challenge, and recently the role of antioxidants has been associated to bone metabolism. Green tea extract is rich in catechins, especially epigallocatechin gallate (EGCG), which may help control osteoporosis damage in bone tissue. This investigation evaluated the efficacy of green tea ingestion containing different concentrations of EGCG in calvaria bone repair of ovariectomized rats. Wistar rats $(n=15)$ were ovariectomized and divided into 3 groups: ovariectomized (OVX), ovariectomized + GTE $15 \%$ EGCG (OVX/GTE15), and ovariectomized + GTE $94 \%$ EGCG (OVX/GTE94). Green tea extract was administered by gavage in the concentration of $50 \mathrm{mg} / \mathrm{kg}$ and sham group $(\mathrm{n}=5)$ received water. Bone defects were performed in the calvaria 60 days after ovariectomy followed by 4 weeks until euthanasia. Bone samples were collected to perform qualitative and quantitative histological analysis of bone formation. Data obtained were submitted to normality and ANOVA statistical test for $\mathrm{p}<0.05$. The mean values of neoformed bone for Sham, OVX, OVX/GTE15 and OVX/GTE94 were respectively: $21.11 \pm 3.91$; $19.92 \pm 2.20$; $33.05 \pm 1.26$ e $34.75 \pm 0.54(\mathrm{p}<0.05)$. Results show that continuous ingestion of green tea extract immediately after ovariectomy shows positive effects in the prevention of bone loss in osteoporosis, even with low concentrations of EGCG.

KEY WORDS: Tea; Catechin; Osteoporosis; Bone; Rats.

\section{INTRODUCTION}

Healthy bone tissue is in constant remodeling, nevertheless, when resorption overwhelms formation, osteoporosis may occur (Appelman-Dijkstra \& Papapoulos, 2016). The etiology of this disease is multifactorial, and among them oxidative stress has been shown to interfere in bone remodelation because of free radicals accumulation which are not normally eliminated, resulting in loss of biological functions and oxidative damage to cells and tissues (Domazetovic et al., 2017).

Researches have been demonstrating that control and treatment of osteoporosis might be reached with antioxidant ingestion, for they participate of free radical control protecting healthy cells from oxidative stress. Antioxidants can be found in vegetables, fruits (Peluso \& Serafini, 2017) and also in green tea (Camellia sinensis L.), which is a popular beverage around the world with positive antimutagenic, antiproliferative, anticancerigen and antioxidant properties. These properties are given by polyphenols contained in green tea extract (GTE), composed mainly by epicatechin (EC), epigallocatechin (EGC), epicatechin-3-gallate (GEC) and epigallocatechin gallate (EGCG). EGCG is the most abundant (Sharifzadeh et al., 2017) and has been associated to osteogenesis (Jin et al., 2015). Green tea extract might be a good alternative in the treatment and prevention of osteoporosis, promoting positive effects on osteoblasts, eliminating free radicals as well as diminishing inflammations (Vester et al., 2014).

Department of Basic and Oral Biology, School of Dentistry of Ribeirão Preto University of São Paulo, Ribeirão Preto, São Paulo, Brazil. We thank FAPESP (São Paulo Research Foundation - Process No. 2016/08720-0), CNPq (National Council for Scientific and Technological Development) and National Institute and Technology - Translational Medicine (INCT.TM) for financial support. 
FREITAS, L. C.; SOUSA, L. G.; LEITE, G. L.; SCALIZE, P. H.; PITOL, D. L.; RIGHETTI, M. A.; RICARDO, V.; MELLO, E. C.; BOMBONATO-PRADO, K. F.; REGALO, S. C. H. \& SIESSERE, S. Influence of green tea extract with different concentrations of epigallocatechin gallate on calvaria bone repair of ovariectomized rats. Int. J. Morphol., 37(4):1325-1330, 2019.

Investigations showed that EGCG increased mineralized nodule formation, suppressed osteoclast differentiation and augmented its apoptosis, as well modulated the expression of bone marker genes in mesenchymal cells, such as Runx2, Sp7 and osteocalcin (Byun et al., 2014). Besides, EGCG may promote osteogenic differentiation in human bone marrow mesenchymal stem cells, with the potential of utilization as a pro-osteogenic agent in the treatment of osteoporosis (Jin et al., 2015). Thus, we hypothesized that: 1 - green tea may influence bone metabolism, 2 - green tea may increase bone formation proportional to higher concentrations of epigallocatechin gallate. The purpose of this investigation was to evaluate the efficacy of green tea ingestion with different concentrations of epigallocatechin gallate in the process of repair in calvaria bone defects of rats submitted to an experimental model of osteoporosis.

\section{MATERIAL AND METHOD}

For the study 20 Wistar female rats weighting $300 \mathrm{~g}$ were used (the experimental protocol was approved by Ethics Committee for Animal Experimentation of the University of São Paulo, Ribeirão Preto, São Paulo, Brazil, permit number 2016.1.372.58.4 and 2017.1.580.58.7). Fifteen animals were anesthetized by an intramuscular injection of xylazine $(10 \mathrm{mg} / \mathrm{kg})$ and ketamine $(75 \mathrm{mg} / \mathrm{kg})$ (Agibrands do Brasil LTDA, Campinas, SP, Brazil). After trichotomy and antisepsis, the ovaries were excised. The tissue suture was performed with silk thread 4.0 (Ethicon, Johnson \& Johnson, São José dos Campos, SP, Brazil). Each animal received an intramuscular injection of $0.1 \mathrm{~mL} / 100 \mathrm{~g}$ weight of small-size veterinary pentabiotic (Pentabiotic Veterinário Pequeno Porte-Fort Dodge $\AA$, Campinas, SP, Brazil) followed by $0.2 \mathrm{~mL} / 100 \mathrm{~g}$ of Banamine ${ }^{\circledR}$ injectable (Injetável Pet-Schering-Plough, Cotia, SP, Brazil). Sham group was composed of 5 animals, which were submitted to ovary exposition followed by their reposition in the abdominal cavity. They also received antibiotics and analgesics immediately after the surgery. The success of the ovariectomy was evaluated by analyzing the estrous cycle (14 days after ovariectomy) and the atrophy of uterine horns during the euthanasia of the animals. Ovariectomized rats were divided into 3 groups: ovariectomized (Ovx), ovariectomized + GTE $15 \%$ EGCG (OVX/GTE15), and ovariectomized + GTE $94 \%$ EGCG (OVX/GTE94).

Administration of green tea extract: Two types of GTE were used: 1) group OVX/GTE15 received GTE produced in China and supplied by Galena Química and Farmacêutica Ltda (Campinas, SP, Brasil); it is characterized by containing
$50 \%$ polyphenols, $30 \%$ catechins, $15 \%$ EGCG and less than $7 \%$ caffeine. 2) group OVX/GTE94 received GTE Sunphenon 90D produced by Taiyo International (Japan), certified by FDA (www.sunphenon.com/formulatorresources), supplied by R\&S Blumos do Brasil (Campinas, SP, Brazil). This extract is characterized by containing $94 \%$ EGCG and less than $0.1 \%$ caffeine. The extracts were administered to the selected groups by gavage in the concentration of $50 \mathrm{mg} / \mathrm{Kg}$ (Minatti et al., 2012; Alway et al., 2015) 24 hours after surgery and in 48 hours-intervals until euthanasia. Sham and Ovx groups received water by gavage in replacement to GTE.

Calvarial surgical defect procedure: Bone defects were created 60 days after ovariectomy. The animals were weighted and anesthetized with an intraperitoneal injection of ketamine $(75 \mathrm{mg} / \mathrm{Kg}$ ) (União Química Farmacêutica Nacional S/A-Embu-Guaçu, SP, Brazil) and xylazine (10 mg/ $\mathrm{Kg}$ ) (Hertape Calier-Juatuba, MG, Brazil). Afterwards, the animals were submitted to trichotomy, antisepsis and a sagittal incision $(1 \mathrm{~cm}$ long) to expose the intended bone area. A critical bone defect of $5 \mathrm{~mm}$ was made in the central region of the left parietal bone using a trephine drill (Neodent, Curitiba, PR, Brazil) and an electric implant motor (Dentscler, Ribeirão Preto, SP, Brazil) at $3000 \mathrm{rpm}$. All animals received intramuscular injection with a single dose of Banamine painkiller-1.1 mg/Kg (MSD Saúde Animal, São Paulo, SP, Brazil) and Pentabiotico Veterinário, Pequeno Porte- $0.1 \mathrm{~mL} / 100 \mathrm{~g}$ (Fort Dodge ${ }^{\circledR}$, Campinas, SP, Brazil. The euthanasia occurred after 4 weeks and the calvaria were collected for histology processing.

Histological processing: After the rats were euthanized, calvaria fragments containing the defect site were collected from each animal and were fixed in buffered $(\mathrm{pH} 7) 10 \%$ formaldehyde solution for 24 hours. The specimens were then washed in running water and decalcified by a solution containing $20 \%$ sodium citrate and $30 \%$ formic acid for 6 days. This solution was replaced every 2 days and neutralized with $5 \%$ sodium sulfate. The specimens were then dehydrated by increasingly concentrate ethanol solution: 70 $\%$ overnight, then $80 \%, 85 \%, 90 \%$, and $95 \%$ for 2 hours each, until $100 \%$. The specimens were then processed with xylol and embedded in paraffin. Longitudinal semiserial sections $6 \mu \mathrm{m}$ thick were stained with hematoxylin and eosin as well as masson trichrome. The analysis was carried out using a Leica DM4000B light microscope (Leica, Bensheim, Germany) outfitted with a Leica DFC310FX.

Qualitative histological analysis: The area of bone defect was analyzed to observe the presence of neoformed bone, as well as inflammatory cells, blood vessels and connective tissue. There were obtained images with objectives of 10x, 
FREITAS, L. C.; SOUSA, L. G.; LEITE, G. L.; SCALIZE, P. H.; PITOL, D. L.; RIGHETTI, M. A.; RICARDO, V.; MELLO, E. C.; BOMBONATO-PRADO, K. F.; REGALO, S. C. H. \& SIESSERE, S. Influence of green tea extract with different concentrations of epigallocatechin gallate on calvaria bone repair of ovariectomized rats. Int. J. Morphol., 37(4):1325-1330, 2019.

20x and 40x by means of a digital camera Leica EC3 and light microscope Leica DM 4000B.

Quantitative histological analysis: The differential point counting method is preconized by Weibel et al. (1966) and was utilized for the analysis of the amount of neoformed bone. The number of images was calculated in accordance to Hally (1964), being obtained 200 images per group (40 images/animal). A test system was elaborated using software Image $\mathbf{J}$ and a grid of 80 points obtained by means of vertical and horizontal intersected lines. To calculate the area of neoformed bone it was utilized the following formula:

$$
\mathrm{A}=\sum \mathrm{Pp} / \sum \mathrm{Pt} \times 100
$$

Where:

A: represents neoformed bone area in $\%$

Pp: points on neoformed bone in the repair area

Pt: total points of test-system (80).

Statistical Analysis: Quantitative data were tabulated and submitted to statistical analysis with the software GraphPad Prism. It was observed a normal distribution for all obtained data (Shapiro Wilk, p>0.05) allowing the utilization of ANOVA and Holm-Sidak test for group comparison.
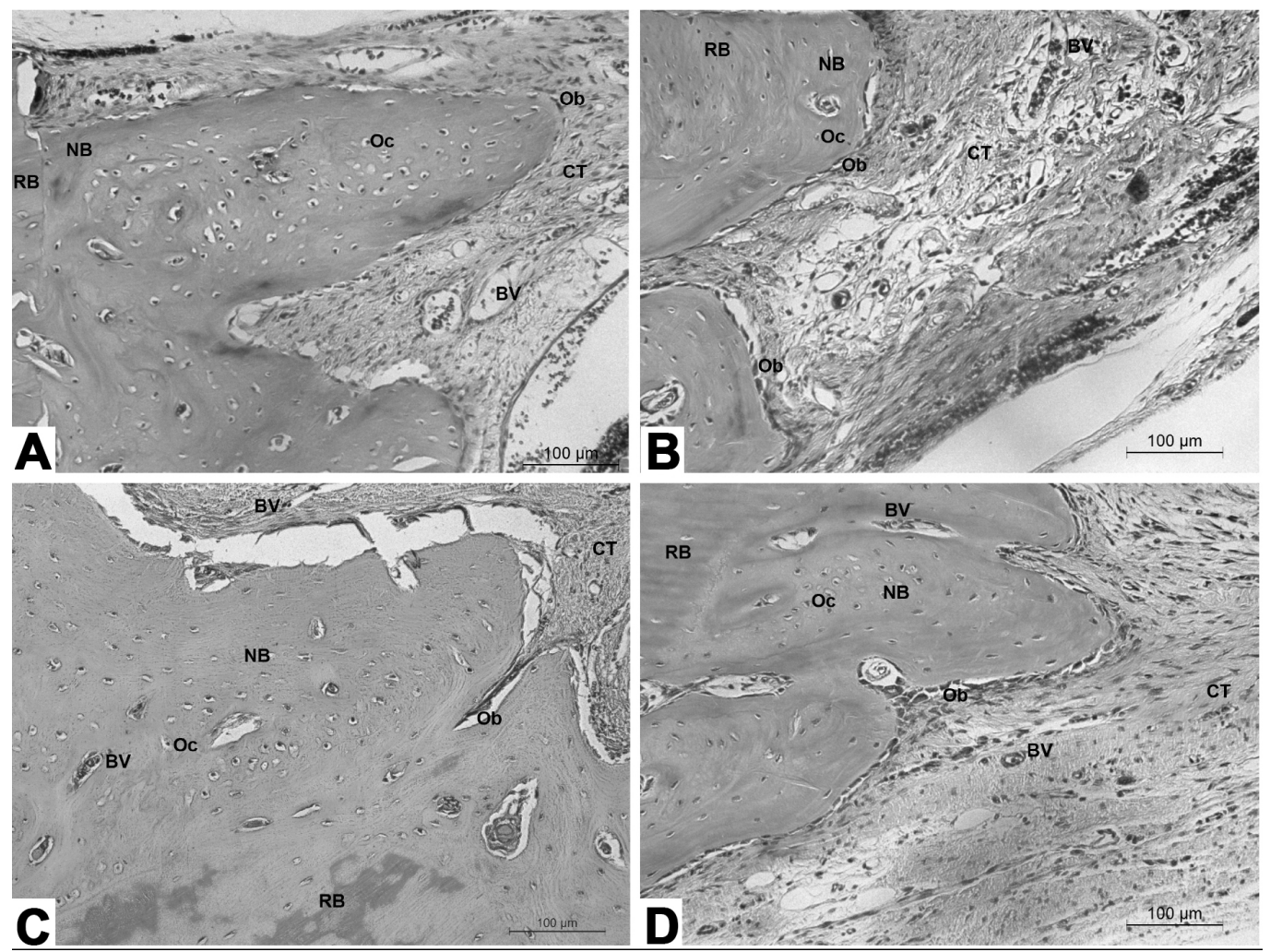

Fig. 1. Photomicrography from peripheral defect bone in the groups. A. Sham; B. Ovariectomized; C. Ovariectomized + GTE15; D. Ovariectomized + GTE94. NB=new bone; $\mathrm{RB}=$ remanescent bone; $\mathrm{Ob}=$ osteoblasts; $\mathrm{Oc}=$ osteocytes; $\mathrm{BV}=$ bone volume; $\mathrm{CT}=$ connective tissue. Bar scale $=100 \mu \mathrm{m}$. Masson trichrome staining.
Morphological analysis: In the histological evaluation the absence of bone formation in the central region of the defect was observed in all evaluated samples, and a dense connective tissue, denser in the groups that received green tea extract. Connective tissue in the central defect of ovariectomized group was thinner when compared to the same region in sham group. Besides, no inflammatory cells infiltrate were observed.

Sham group presented bone neoformation in the periphery of bone defect, lined by a unique layer of osteoblasts (Fig. 1A). In the group of ovariectomized rats, connective tissue presented a great amount of collagen fibers, as well as neoformed bone lined by elongated or voluminous osteoblasts depending on the region (Fig. 1B). Both sham and OVX groups presented osteocytes inside lacunae and blood vessels in adjacent connective tissue (Figs. 1A and 1B). The animals that receive green tea presented a great amount of neoformed bone in the periphery of the defect, with osteocytes and peripheral osteoblasts, as well as blood vessels in the connective tissue (Figs. 1C and 1D). 
FREITAS, L. C.; SOUSA, L. G.; LEITE, G. L.; SCALIZE, P. H.; PITOL, D. L.; RIGHETTI, M. A.; RICARDO, V.; MELLO, E. C.; BOMBONATO-PRADO, K. F.; REGALO, S. C. H. \& SIESSERE, S. Influence of green tea extract with different concentrations of epigallocatechin gallate on calvaria bone repair of ovariectomized rats. Int. J. Morphol., 37(4):1325-1330, 2019.

Quantitative analysis: The animals that received green tea presented the great amount of neoformed bone. The mean values of neoformed bone for the animals from Sham, OVX, OVX/GTE15, OVX/GTE94 groups were respectively: 21.11 $\pm 3.91 ; 19.92 \pm 2.20 ; 33.05 \pm 1.26$ and $34.75 \pm 0.54$. OVX/ GTE15 group presented a significantly greater area when compared to groups Sham e OVX $(\mathrm{p}<0.0001$ and $\mathrm{p}=0.0001$, respectively). The same way, OVX/GTE94 presented a significantly greater neoformed bone area when compared to Sham and OVX groups $(\mathrm{p}<0.0001$ and $\mathrm{p}=0.0002$, respectively). There was no statistical difference between Sham and OVX groups $(\mathrm{p}=0.9993)$ and between OVX/ GTE15 and OVX/GTE94 groups (p=0.8711) (Fig. 2).

\section{Bone Formation}

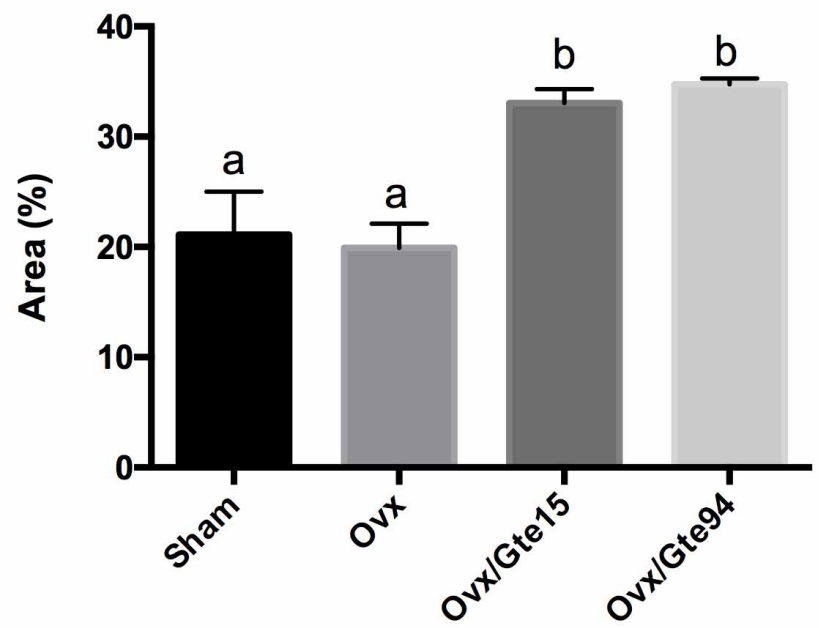

Fig. 2. Mean values of neoformed bone (\%) in Sham, Ovx, OVX/ GTE15 e OVX/GTE94. Different letters mean statistical difference.

\section{DISCUSSION}

The present investigation evaluated the systemic effects of green tea extract with more than $15 \%$ and $94 \%$ EGCG in animals submitted to an experimental model of osteoporosis. Bilateral ovariectomy in rats has been widely utilized to simulate bone loss promoted by osteoporosis, permitting evaluation of morphological changes in bone repair (Hsu et al., 2016; Calciolari et al., 2017; Shulgau et al., 2017).

Histomorphometric results revealed that the mean values of bone neoformation between sham and ovariectomized groups were similar, without statistical significance. These data are in agreement with previous results obtained by our group research (Scalize et al., 2016), despite the high mean values obtained for bone neoformation in OVX group. Nevertheless, these results are different from Yu et al. (2012), who stated that ovariectomized animals commonly present increased bone formation when compared to control in an attempt to repair the metabolism in a situation of osteoporosis. Our results also differ from Durão et al. (2012), who observed a decrease in bone neoformation in 6-month calvaria defects of OVX group when compared to control.

Despite several reports found in the literature about the utilization of green tea extract in animals with or without estrogen deficiency, few have investigated its effect in calvaria bone defects. Besides, the diversity of concentrations and administration methods do not favor a comparison of the studies.

Our first hypothesis was confirmed, showing that the animals that received green tea extract had a significant increase in bone neoformation when compared to OVX and sham group. Our results are in agreement to Rodriguez et al. (2011), which even using a different methodology from our study, demonstrated that local application of EGCG promotes bone neoformation in rat calvaria bone when associated to a-tricalcium phosphate. The increase in bone neoformation found in our study can be explained by the fact that green tea catechins have an impact in bone remodeling modulating osteoblast and adipocyte differentiation. Bone marrow stem cells may differentiate in osteoblasts, condroblasts, adipocytes, myoblasts and stromal cells. EGCG stimulates mesenchymal stem cells directing them to osteogenic lineage by means of MAPK/ ERK (mitogen activated protein kinase/extracellular signalregulated kinases) suppression and induction of $\mathrm{PP} 2 \mathrm{~A}$ (protein phosphatase 2A), increasing alkaline phosphatase activity as well as the expression Runx2, ALP, OPN and OC genes. This catechin also suppresses adipocyte differentiation and induces its apoptosis, beta-oxidation of fatty acids and lipolysis (Shen et al., 2013). In agreement with Jin et al. (2014), EGCG is capable to direct osteogenic differentiation by continuous regulation of Runx2, besides modulating bone morphogenetic protein 2 (Bmp2). Other researches verified that the treatment of human osteoblasts with EGCG promotes mineralized matrix formation and expression of ALP and BSP genes. The increase in levels of ALP would be a direct indicator of osteoblastogenesis as well as indirect for augmenting mineralization (Mah et al., 2014).

The effects of EGCG on bone tissue were also studied by Liu et al. (2018), both in vivo and in vitro. These authors demonstrated in vitro that EGCG is capable of increasing osteoblast viability as well as ALP and superoxide dismutase activity in rats with osteoporosis by glucocorticoid 
utilization. EGCG can reduce ROS (reactive oxygen species) in osteoblasts activating $\mathrm{Nrf} 2$, an important regulator of antioxidant body response and suppressor of osteoblastic apoptosis. Besides, this catechin enhances in vivo bone microstructure and minimizes deterioration of bone quality induced by glucocorticoids.

Our second hypothesis was rejected after demonstration that mean values of bone neoformation were similar for animals that received green tea with more than $15 \%$ EGCG (33.05 \pm 1.26$)$ and $94 \%$ EGCG (34.75 \pm 0.54$)$. Mah et al. verified that high concentrations of EGCG may promote negative effects both in vitro and in vivo. To these authors, clinical application of EGCG in an adequate concentration might stimulate osteoblast activity, whereas high concentrations could diminish the activity of these cells. The concentration of $50 \mathrm{mg} / \mathrm{Kg}$ used in this study was based on the reports of Minatti et al. and Alway et al. showing an increasing in bone neoformation in those animals treated with green tea immediately after ovariectomy. Even though not evaluated in this investigation, it is possible that green tea administered right after ovariectomy might have enhanced bone mineral density, like stated by other authors when studying femur remodeling (Shen et al., 2008). A recent meta-analysis investigation reported benefits of green tea extract associated to bone mineral density especially in lumbar spine, hips and femur, which can help prevention of bone loss (Zhang et al., 2017).

In conclusion, with the obtained results, it is suggested that green tea extracts (15\% and $94 \%$ EGCG) may have positive effects in systemic conditions like osteoporosis, inducing a significant bone neoformation in osteoporotic rats. The results also suggest that green tea extract, when used in a continuous way immediately after ovariectomy, may be used as a coadjuvant in the treatment and prevention of bone loss in osteoporosis, even with low concentrations of EGCG.

Influence of green tea extract with different concentrations of epigallocatechin gallate on calvaria bone repair of ovariectomized rats.

\section{ACKNOWLEDGEMENTS}

We thank FAPESP (São Paulo Research Foundation - Process No. 2016/08720-0), CNPq (National Council for Scientific and Technological Development) and National Institute and Technology - Translational Medicine (INCT.TM) for financial support.
FREITAS, L. C.; SOUSA, L. G.; LEITE, G. L.; SCALIZE, P. H.; PITOL, D. L.; RIGHETTI, M. A.; RICARDO, V.; MELLO, E. C.; BOMBONATO-PRADO, K. F.; REGALO, S. C. H. \& SIESSERE, S. Influencia del extracto de té verde con diferentes concentraciones de galato de epigalocatequina sobre la reparación ósea de calvaria de ratas ovariectomizadas. Int. J. Morphol., 37(4):1325-1330, 2019.

RESUMEN: La disminución en la progresión de la osteoporosis es un desafío, y recientemente el papel de los antioxidantes se ha asociado al metabolismo óseo. El extracto de té verde es rico en catequinas, especialmente el galato de epigalocatequina (EGCG), lo que puede ayudar a controlar el daño de la osteoporosis en el tejido óseo. Esta investigación evaluó la eficacia de la ingesta de té verde con diferentes concentraciones de EGCG en la reparación ósea de calvaria de ratas ovariectomizadas. Las ratas Wistar $(n=15)$ fueron ovariectomizadas y divididas en 3 grupos: ovariectomizadas (OVX), ovariectomizadas + GTE $15 \%$ EGCG (OVX / GTE15), y ovariectomizadas + GTE 94 \% EGCG (OVX / GTE94). El extracto de té verde se administró por sonda en una concentración de $50 \mathrm{mg} / \mathrm{kg}$ y el grupo simulado $(\mathrm{n}=5)$ recibió agua. Los defectos óseos se realizaron en la calvaria 60 días después de la ovariectomía, seguido de 4 semanas hasta la eutanasia. Se obtuvieron muestras de hueso para realizar un análisis histológico cualitativo y cuantitativo de la formación ósea. Los datos obtenidos se sometieron a normalidad y prueba estadística ANOVA $(p<0,05)$. Los valores medios de hueso neoformado para Sham, OVX, OVX / GTE15 y OVX / GTE94 fueron: 21,11 \pm 3,$91 ; 19,92 \pm 2,20 ; 33,05 \pm 1,26$ y $34,75 \pm 0,54$ ( $p<0,05$ ), respectivamente. Los resultados muestran que la ingesta continua de extracto de té verde, inmediatamente después de la ovariectomía, muestra efectos positivos en la prevención de la pérdida ósea ocurrida en la osteoporosis, incluso con concentraciones bajas de EGCG.

PALABRAS CLAVE: Té; Catequina; Osteoporosis; Hueso; Ratas.

\section{REFERENCES}

Alway, S. E.; Bennett, B. T.; Wilson, J. C.; Sperringer, J.; Mohamed, J. S.; Edens, N. K. \& Pereira, S. L. Green tea extract attenuates muscle loss and improves muscle function during disuse, but fails to improve muscle recovery following unloading in aged rats. J. Appl. Physiol. (1985), 118(3):319-30, 2015

Appelman-Dijkstra, N. M. \& Papapoulos, S. E. From disease to treatment: from rare skeletal disorders to treatments for osteoporosis. Endocrine, 52(3):414-26, 2016.

Byun, M. R.; Sung, M. K.; Kim, A. R.; Lee, C. H.; Jang, E. J.; Jeong, M. G.; Noh, M.; Hwang, E. S. \& Hong, J. H. (-)-Epicatechin gallate (ECG) stimulates osteoblast differentiation via Runt-related transcription factor 2 (RUNX2) and transcriptional coactivator with PDZ-binding motif (TAZ)-mediated transcriptional activation. J. Biol. Chem., 289(14):9926-35, 2014.

Calciolari, E.; Mardas, N.; Dereka, X.; Kostomitsopoulos, N.; Petrie, A. \& Donos, N. The effect of experimental osteoporosis on bone regeneration: Part 1, histology findings. Clin. Oral Implants Res., 28(9):e101-e110, 2017. 
Domazetovic, V.; Marcucci, G.; Iantomasi, T.; Brandi, M. L. \& Vincenzini, M. T. Oxidative stress in bone remodeling: role of antioxidants. Clin. Cases Miner. Bone Metab., 14(2):209-16, 2017.

Durão, S. F.; Gomes, P. S.; Silva-Marques, J. M.; Fonseca, H. R.; Carvalho, J. F.; Duarte, J. A. \& Fernandes, M. H. Bone regeneration in osteoporotic conditions: healing of subcritical-size calvarial defects in the ovariectomized rat. Int. J. Oral Maxillofac. Implants, 27(6):1400-8, 2012.

Hally, A. D. A counting method for measuring the volumes of tissue components in microscopical sections. J. Cell Sci., s3-105:503-17, 1964.

Hsu, P. Y.; Tsai, M. T.; Wang, S. P.; Chen, Y. J.; Wu, J. \& Hsu, J. T. Cortical bone morphological and trabecular bone microarchitectural changes in the mandible and femoral neck of ovariectomized rats. PLoS One., 11(4): $\mathrm{e} 0154367,2016$

Jin, P.; Li, M.; Xu, G.; Zhang, K.; Zheng, L. \& Zhao, J. Role of (-)epigallocatechin-3-gallate in the osteogenic differentiation of human bone marrow mesenchymal stem cells: An enhancer or an inducer? Exp. Ther. Med., 10(2):828-34, 2015.

Jin, P.; Wu, H.; Xu, G.; Zheng, L.; \& Zhao, J. Epigallocatechin-3-gallate (EGCG) as a pro-osteogenic agent to enhance osteogenic differentiation of mesenchymal stem cells from human bone marrow: an in vitro study. Cell Tissue Res., 356(2):381-90, 2014.

Liu, S.; Yang, L.; Mu, S. \& Fu, Q. Epigallocatechin-3-gallate ameliorates glucocorticoid-induced osteoporosis of rats in vivo and in vitro. Front. Pharmacol., 9:447, 2018.

Mah, Y. J.; Song, J. S.; Kim, S. O.; Lee, J. H.; Jeon, M.; Jung, U. W.; Moon, S. J.; Kim, J. H. \& Choi, H. J. The effect of epigallocatechin-3-gallate (EGCG) on human alveolar bone cells both in vitro and in vivo. Arch. Oral Biol., 59(5):539-49, 2014.

Minatti, J.; Wazlawik, E.; Hort, M. A.; Zaleski, F. L.; Ribeiro-do-Valle, R. M.; Maraschin, M. \& da Silva, E. L. Green tea extract reverses endothelial dysfunction and reduces atherosclerosis progression in homozygous knockout low-density lipoprotein receptor mice. Nutr. Res., 32(9):684-93, 2012.

Peluso, I. \& Serafini, M. Antioxidants from black and green tea: from dietary modulation of oxidative stress to pharmacological mechanisms. Br. J. Pharmacol., 174(11):1195-208, 2017.

Rodriguez, R.; Kondo, H.; Nyan, M.; Hao, J.; Miyahara, T.; Ohya, K. \& Kasugai, S. Implantation of green tea catechin a-tricalcium phosphate combination enhances bone repair in rat skull defects. J. Biomed. Mater. Res. B Appl. Biomater., 98(2):263-71, 2011.

Scalize, P. H.; Bombonato-Prado, K. F.; de Sousa, L. G.; Rosa, A. L.; Beloti, M. M.; Semprini, M.; Gimenes, R.; de Almeida, A. L.; de Oliveira, F. S.; Hallak Regalo, S. C.; et al. Poly(Vinylidene FluorideTrifluorethylene)/barium titanate membrane promotes de novo bone formation and may modulate gene expression in osteoporotic rat model. J. Mater. Sci. Mater. Med., 27(12):180, 2016.

Sharifzadeh, M.; Ranjbar, A.; Hosseini, A. \& Khanavi, M. The effect of green tea extract on oxidative stress and spatial learning in streptozotocin-diabetic rats. Iran. J. Pharm. Res., 16(1):201-9, 2017.

Shen, C. L.; Kwun, I. S.; Wang, S.; Mo, H.; Chen, L.; Jenkins, M.; Brackee, G.; Chen, C. H. \& Chyu, M. C. Functions and mechanisms of green tea catechins in regulating bone remodeling. Curr. Drug Targets, 14(13):1619-30, 2013.

Shen, C. L.; Wang, P.; Guerrieri, J.; Yeh, J. K.; \& Wang, J. S. Protective effect of green tea polyphenols on bone loss in middle-aged female rats. Osteoporos. Int., 19(7):979-90, 2008.

Shulgau, Z.; Sergazy, S.; Krivoruchko, T.; Kenzhebayeva, N.; Sagindykova, B. \& Gulyayev, A. Osteoprotective properties of RNA-containing drug Osteochondrin $\mathrm{S}$ on the model of insufficiency of sex hormones in rats. Int. J. Morphol., 35(4):1233-8, 2017.

Vester, H.; Holzer, N.; Neumaier, M.; Lilianna, S.; Nüssler, A. K. \& Seeliger, C. Green Tea Extract (GTE) improves differentiation in human osteoblasts during oxidative stress. J. Inflamm. (Lond)., 11:15, 2014.

Weibel, E. R.; Kistler, G. S. \& Scherle, W. F. Practical stereological methods for morphometric cytology. J. Cell Biol., 30(1):23-38, 1966.
Yu, S. J.; Liu, H. C.; Ling-Ling, E.; Wang, D. S. \& Zhu, G. X. Proliferation and differentiation of osteoblasts from the mandible of osteoporotic rats. Exp. Biol. Med. (Maywood), 237(4):395-406, 2012.

Zhang, Z. F.; Yang, J. L.; Jiang, H. C.; Lai, Z.; Wu, F. \& Liu, Z. X. Updated association of tea consumption and bone mineral density: A metaanalysis. Medicine (Baltimore), 96(12):e6437, 2017.

Corresponding author:

Selma Siessere

Faculdade de Odontologia de Ribeirão Preto

Universidade de São Paulo

Avenida do Café, s/n

Ribeirão Preto - SP

BRAZIL

Email: selmas@forp.usp.br

Received: 17-04-2019

Accepted: 24-06-2019 